\title{
Research on the Application of Information Technology in College English Teaching against the Background of Internet
}

\author{
Jun Chen \\ Fuzhou Melbourne Polytechnic \\ Fuzhou, China
}

\begin{abstract}
Traditional College English teaching is dull, students' initiative in learning is difficult to mobilize, and the teaching effect is not significant. By building information technology-based teaching platforms which rely on the Internet and mobile terminals, and adopting online and offline blended teaching mode, students' principal position is highlighted. Under the guidance of teachers, students use information technology software to carry out personalized learning before, during and after class. The application of information technology in teaching has stimulated students' interest in learning English, fostered their ability of autonomous learning, promoted the internalization and absorption of knowledge, and improved the teaching quality and effect. This research provides new ideas for the reform of college English teaching.
\end{abstract}

Keywords-Internet; information technology; teaching mode; college English

\section{INTRODUCTION}

In the process of College English teaching and learning, teachers often adopt the traditional "full classroom" teaching method, focusing only on the imparting of language points. Students' dominant position in the classroom becomes a mere formality, and teachers force students to receive tasks for learning regardless of their own learning capacity. Therefore traditional college English teaching is dull, the pressure on students is heavy, and there is a lack of effective teaching strategies and learning strategies. This teaching mode, which emphasizes knowledge points and theory, is easily subject to the limitation of time and space. At the same time, it weakens the students' self-learning ability. Students can not carry out personalized learning according to their own actual situation, resulting in the loss of interest in learning as well as their motivation. The reform of traditional English teaching is imperative.

"Internet + " is a new form of Internet development. It constantly promotes the integration of the Internet and traditional industries, and promotes the reform and innovation of various industries through the use of Internet technology and information platform, as well as its ability to collect big data and optimize resource allocation. Under such circumstance, the reform of traditional education has also come into being. "Internet + education" has become the development trend of education in China. Constructing an information technology-based teaching platform based on
Internet and mobile terminal and creating the combination of online and offline blended teaching mode provide more chances and possibilities for college English teaching, which is a new trend of college English teaching reform and further promotes the improvement of teaching quality [1].

\section{ADVANTAGES OF THE USE OF INFORMATION TECHNOLOGY IN ENGLISH TEACHING}

\section{A. Give Priority to Students}

In the traditional teaching mode, teachers occupy the leading position. The primary task of teaching is to instill language points and theories into students. Students' individual differences such as different cognitive structures are ignored. Students learn passively with their weak learning motivation. Integrating information technology into teaching has changed the traditional cramming education, and students' principal position is highlighted. The information technology software helps students adjust their learning progress and workload according to their own learning characteristics and learning habits. The software can also help students carry out personalized learning tasks, reduce the dullness of learning, and further eliminate students' resistance to study.

\section{B. Greater Diversity of Information Technology-Based Teaching Methods}

The use of the Internet, mobile terminals and various information technology-based means to assist English teaching enriches the form of teaching and learning. With the help of information technology-based teaching methods, teachers guide students to carry out various tasks, so that students can actively participate in the whole process of preclass preparation, classroom learning and after-class review and promotion. Teachers give full play to the advantages of online platforms for teaching, which strengthen the interaction between teachers and students, follow up students' learning and progress, and check the students' real time evaluation feedback, so as to achieve an overall supervision of students before class, during the class and after class. Because of the greater diversity of information technology-based teaching methods, teachers can implement and reach their teaching objectives more easily and effectively. 


\section{A Variety of Evaluation Methods}

Various kinds of information technology-based software provide more forms and possibilities for the multi-evaluation system. Teachers and students use information technologybased software to give comment and evaluate each other, and the software provides real time data feedback for students' performance. The evaluation and assessment with multiparticipation highlights objectivity and impartiality. The timely feedback from information technology-based software helps students realize their strength and weakness, so as to adjust their learning styles. It helps teachers optimize their teaching methods at the same time. This diversified evaluation system, which combines students' mutual evaluation, evaluation assisted by software and teachers' evaluation, replaces the traditional method of evaluation which uses the results of the final examination to determine students' learning outcomes, objectively evaluating the students' learning process [2]. The evaluation system with multi-participation enables students to participate in the evaluation itself, which improves students' sense of participation and promotes the development of studying initiative.

\section{CONSTRUCTING INFORMATION TECHNOLOGY-BASED PLATFORMS FOR ENGLISH BLENDED TEACHING}

The English blended teaching mode, which combines online and offline, relies on the information technology-based teaching platforms with the help of Internet and mobile terminals. The construction of information technology-based platforms needs the support from both colleges and teachers.

\section{A. Colleges}

In terms of colleges, they build environments, resources and platforms. Colleges build both hardware and software environments which are needed for the English blended teaching, including the Internet, servers, mobile online terminals, smart classrooms, databases, teaching software, management software and so on. In addition, colleges also need to build information technology-based resources such as online courses, virtual reality, simulation software, and teaching management platforms which assist teaching and provide a variety of data feedback automatically and timely.

\section{B. Teachers}

In terms of teachers, they use online platforms for teaching, "So Jump" app which is used for questionnaires, Quizlet app which is for vocabulary teaching and learning, the Pigai system which is used for marking and analyzing students' exercises and other information technology-based means including social platforms to assist them in teaching. Meanwhile, teachers introduce flipped classroom, microlecture and other teaching methods into class. Integrating multiple and practical information technology into traditional college English teaching, together with the English blended teaching mode combining online and offline before, during and after class highlights the students' principal position. Students conduct interactive learning under the organization, guidance and planning of teachers to complete a variety of English learning tasks.

\section{THE IMPLEMENTATION OF INFORMATION TECHNOLOGY IN COLLEGE ENGLISH TEACHING}

\section{A. Preparations before Class}

Before the class, teachers prepare lessons by making full use of the Internet and information technology such as the database for English teaching, online resources, micro-lecture videos, the apps of "So Jump" and Quizlet, and online platforms for teaching. Teachers assign the pre-class learning tasks to students through these information technology-based software and follow up students' learning progress through the real-time data feedback provided by the software. According to the real-time data feedback in the background, teachers find out the problems faced by students, analyze the problems, and further establish the teaching direction and breakthrough points, so as to prepare more targeted content for the class and improve the quality of teaching. The detailed implementation is as follows:

- Analyze the students and their learning situation with the help of "So Jump" app. The analysis of the students to be taught and their learning situation is the key to producing a great lesson for students. Through the analysis, teachers will know students' existing knowledge reserves, cognitive structure and personalized differences, which will make a great difference to the determination of important and difficult points in teaching, the formulation of teaching strategies and the achievement of teaching objectives [3]. Before class, teachers can set up questions and issue questionnaires to students by using the app "So Jump", with the aim to understand the overall situation of students. After the students submit the questionnaires, the app will automatically generate the data of each question. Teachers will analyze overall situation of students according to the data feedback, and then carry out targeted preparation for the lesson.

- Make full use of database for English teaching. In the pre-class preparation stage, teachers can use the database for English teaching to prepare a lesson. The curriculum resources in the database include audios, videos, animations, texts, a collection of pictures, vocabulary lists, grammar points, e-books, e-teaching materials, teaching courseware, exercises, etc. Making full and rational use of the curriculum resources can not only enrich the content for class, but also can make the class interesting and improve students' interest in learning.

- Make videos of micro-lectures. In addition to the above teaching resources, teachers can also make microlecture videos and send them to students through the online platform for teaching to help students prepare and preview language points before class. The microlecture videos include the main points of knowledge to be taught in the class, covering the key points and difficult points, supplemented by various audios and videos related materials and exercises. The making of micro-lecture videos should take students' different English level and their learning ability into account, 
and match the teaching objectives and teaching progress at all levels [4]. The advantage of learning language points through micro-lecture videos is that students can flexibly adjust their learning progress according to their own learning level, which fully respects individual differences, encourages students to study independently, and improves their self-learning ability.

- Issue vocabulary learning tasks to students through the app Quizlet. Teachers use the app Quizlet to create classes and issue vocabulary learning sets for new lessons before class. Students join classes and search vocabulary learning sets designated and shared by teachers to help them preview and learn the new words, overcoming the difficulties of memorizing the vocabulary. Students browse the vocabulary cards made by teachers, and use the functions of learning, writing, spelling and testing which are provided by the app to preview and learn vocabulary by themselves before class [5]. Matching games, gravity games and other various games and activities in the app increase the interest of vocabulary learning, which attracts students' attention and reduces the boredom of learning. Students complete the vocabulary learning tasks for the new lesson before class. With the help of the app, students learn the vocabulary by doing and practicing, and then learn to play and play to learn. Teachers can check students' learning process and time spent on learning, and also identify the difficulty of the vocabulary for students in real time according to the data feedback from the app. Then, teachers further determine the key and difficult points of vocabulary learning in the class, so as to make classroom teaching more targeted.

- Build online platforms for teaching. The platforms build the online teaching and learning platforms for teachers and students with the help of the Internet and mobile terminals. In order to enable students to start preview lessons in advance, teachers create classes, upload course materials (including courseware, microlecture videos, etc.) before class, assign preview tasks, and initiate thematic discussions through the online platforms. Students $\log$ in, check all the learning materials, receive and complete various learning tasks, and they can also share learning resources with each other in the discussion area and publish any doubts in the process of preview. Teachers and students actively participate in discussions and exchanges views and suggestions interactively. On the basis of the discussion and students' learning progress, teachers make adjustments to the content of the lecture to be taught accordingly.

\section{B. Classroom Teaching}

Information technology-based platforms provide various teaching resources for college English classroom teaching. Teachers use different information technology according to different teaching objectives, which not only makes teaching and learning convenient and efficient, but also makes teaching activities diversified, and promotes the traditional classroom teaching offline to release more vitality. Teachers give full play to the role of guidance. They organize, guide and promote various learning tasks, to help students achieve learning by practicing instead of just taking notes all the time in the class without interaction. In the process of English classroom teaching, teachers can make full use of online teaching platforms, "So Jump" app and other kinds of teaching software, to serve the teaching and make sure the whole process efficient and fruitful. The detailed implementation is as follows:

- Use online teaching platforms to assist classroom teaching. In class, teachers use the sign-in and call-in function of the online teaching platforms to let students check in at one click. Compared with the traditional way of call-in, teachers can save a lot of classroom time, and students' absence is clear at a glance. The whole class is carried out in the way of group cooperation. Teachers randomly divide students into groups through the grouping function of the online teaching platforms. Teachers create real life situations, publish in-class tasks in the interactive area of the online teaching platforms. Students receive tasks, read relevant information about the tasks, and comment in the discussion area through their mobile phones or tablets. While discussing the key and difficult points of the lesson, the teachers show the questions raised by the students in the discussion area on the scream and guide the students to discuss the problems in class. Subsequently, the students complete the tasks issued by the teachers in groups. Team members look for information on the Internet, analyze the tasks, sort out the materials, and upload the photos of the group work to the online teaching platforms. Students can see the works of other groups and select the best work in the voting area of the online teaching platforms, and then comment on them or give likes. Finally, at the end of the class each student writes down the main points of the class (words or sentences are acceptable) or draws a mind map in limited time. They take pictures and upload them in the discussion area of the online teaching platforms. During the whole teaching process, teachers score in real time on the online teaching platforms according to the individual or group performance for each task in class. Teachers check the students' questions and comments in the discussion area and give feedback immediately during the class, adjusting and improving the content of the lecture at any time.

- Use the Pigai system to assist English teaching. Teachers assign in-class exercises through the Pigai system. In addition to the common function of composition writing, the exercises in the system also include reading, listening, speaking, translation and other types of exercises. Online exercises are carried out in conjunction with college English reading, listening, writing, spoken English and other courses. After submitting the exercises students have finished, the system will mark your works and give comments 
word by word on spelling, vocabulary and grammar. It will also check whether the expressions are standard and the structures are logical and consistent. Finally, the system will give the overall evaluation, comments for revision and the specific scores as well [6]. According to the feedback, students can understand the problems they might have in the first time, correct the mistakes in time, and improve their works. Students can also know their ranking in the class, see other students' exercises and learn from others. Teachers make timely comments and analysis with the overall data feedback from the system. The use of the system can improve the efficiency of classroom practice, promote students' self-evaluation and mutual evaluation, improve students' autonomous learning ability and their studying initiative, and significantly improve their English listening, speaking, reading, writing and translation.

- Use the "So Jump" app to carry out in-class tests. Teachers use the testing function of the app to conduct in-class tests to examine students' mastery of language points. The questions in the questionnaires and length of in-class test are flexibly decided by teachers. After the students submit the test papers, the app will automatically mark and count the scores in the background. Students can check the scores and rankings immediately. Teachers show the correct rate of each question students have answered, analyze the reasons why the students make mistakes, and point out the weak links to students. In this way, students can recognize their strength and weakness, and consolidate what they have learned again.

\section{Consolidation and Promotion after Class}

After class, students need to make a report on what they have learned from the class. Teachers provide students with real life situations and some questions for them to answer. According to the given situation, students analyze the context and answer the questions by using what they have learned in class, which can be presented by videos, audios, speeches or compositions. Afterwards, the works are uploaded to the discussion area of the online teaching platforms, and the students score their own works and give comment on other students' works. This is an important step to reflect on the knowledge learned by students themselves before class and the language points absorbed in class, which further develops students' self-learning ability and students' ability to use language comprehensively. Integrating various forms of information technology-based means into the promotion part after class is conducive to arousing students' interest and enthusiasm in English learning, and promotes the active construction of knowledge in a much better way.

\section{CONCLUSION}

Under the background of Internet, the application and innovation of information technology in the field of education is of great significance to the reform of college English curriculum, which puts forward higher requirements for teaching and learning and promotes the improvement of education quality. Teachers use information technology-based teaching methods, use online and offline blended teaching mode, and highlight the dominant position of students. In this way, teachers can also be released from the pressure of fullroom irrigation. Of course, teachers should try to avoid the following problems while they are using the information technology-based teaching methods. The first problem is that teachers attach more importance to information technology and less importance to the practical application and knowledge itself. Another problem is that colleges can not meet the needs of teachers and students in the construction of hardware and software facilities such as online teaching resources and platforms. The third problem is that teachers' leading position might be absent. All of these put forward higher requirements for the construction of online teaching platforms and teachers' comprehensive ability. In order to create a better information technology-based teaching and learning environment for teachers and students, teachers also need to further enhance the ability of technology application, data acquisition and processing, resource integration and creation, and classroom teaching. All of the improvements can not only strengthen students' comprehensive English application ability effectively, but also promote the reform and development of college English teaching.

\section{REFERENCES}

[1] Yuqian. Xing, "Exploration on the effectiveness of the blended teaching model of college English for arts and sports," English Square, vol. 09, 2019, pp. 61-62.

[2] Chunxiu. He and Dan. Wang, "A study on multivariate evaluation of college English blended learning model," Journal of Wenzhou Medical College, vol. 09, 2017, pp. 695-697.

[3] Caixin. Zhao and Yueping. Wang, Preparing Lessons: From Learning Situation Analysis to Teaching Design, Jiangsu: Jiangsu Science and Technology Press, 2015, pp. 32-33.

[4] Yun. Chen and Chen. Han, "Research on the model of college ora English flipped classroom based on micro-lecture: a case study of Guizhou Normal University," Journal of Liupanshui Normal University, vol. 03, 2019, pp. 103-108.

[5] Jing. Zeng, "Application of quizlet in English listening and speaking teaching in higher vocational college," Crazy English (Theoretical Version), vol. 04, 2018, pp. 126-127.

[6] Zhen. Wang, "On the integrated English literature teaching mode based on www.pigai.org," Journal of Huaihai Institute of Technology (Humanities and Social Sciences), vol. 07, 2019, pp. 132-135. 